\title{
Correction to: The possible role of visceral fat in early pregnancy as a predictor of gestational diabetes mellitus by regulating adipose-derived exosomes miRNA-148 family: protocol for a nested case-control study in a cohort study
}

Zhenhong Zhang ${ }^{1+}$, Qian Xü ${ }^{2+}$, Yanping Chen ${ }^{2}$, Lun Sui ${ }^{2}$, Lu Jiang ${ }^{2}$, Qianqian Shen ${ }^{1}$, Minyu Li ${ }^{1}$, Guoju Li ${ }^{2^{*}}$ and Qiuzhen Wang ${ }^{1 *}$ (D)

Correction to: BMC Pregnancy Childbirth 21, 262 (2021) https://doi.org/10.1186/s12884-021-03737-1

Following publication of the original article [1], the authors reported an error in the author-group. Qiuzhen Wang is also the corresponding author.

Zhenhong Zhang ${ }^{1+}$, Qian $\mathrm{Xu}^{2 \dagger}$, Yanping $\mathrm{Chen}^{2}$, Lun $\mathrm{Sui}^{2}$, Lu Jiang ${ }^{2}$, Qianqian Shen ${ }^{1}$, Minyu $\mathrm{Li}^{1}$, Guoju $\mathrm{Li}^{{ }^{2}}$ and Qiuzhen Wang ${ }^{1 *}$

The original article has been updated.

Published online: 24 September 2021

\section{Reference}

1. Zhang Z, Xu Q, Chen Y, Sui L, Jiang $L$, Shen $Q$, et al. The possible role of visceral fat in early pregnancy as a predictor of gestational diabetes mellitus by regulating adipose-derived exosomes miRNA-148 family: protocol for a nested case-control study in a cohort study. BMC Pregnancy Childbirth. 2021;21:262 https://doi.org/10.1186/s12884-021-03737-1.

The original article can be found online at https://doi.org/10.1186/s12884021-03737-1.

*Correspondence: liquoju0532@126.com; qdwangqiuzhen@126.com †Zhenhong Zhang and Qian Xu contributed equally to this work.

${ }^{2}$ Qingdao Women and Children's Hospital, Qingdao University, No.6 Tongfu

Road Shandong Province, Qingdao 266000, China

${ }^{1}$ Public Health School, Medical College of Qingdao University, Qingdao,

China

C C The Author(s). 2021 Open Access This article is licensed under a Creative Commons Attribution 4.0 International License, which permits use, sharing, adaptation, distribution and reproduction in any medium or format, as long as you give appropriate credit to the original author(s) and the source, provide a link to the Creative Commons licence, and indicate if changes were made. The images or other third party material in this article are included in the article's Creative Commons licence, unless indicated otherwise in a credit line to the material. If material is not included in the article's Creative Commons licence and your intended use is not permitted by statutory regulation or exceeds the permitted use, you will need to obtain permission directly from the copyright holder. To view a copy of this licence, visit http://creativecommons.org/licenses/by/4.0/ The Creative Commons Public Domain Dedication waiver (http://creativecommons.org/publicdomain/zero/1.0/) applies to the data made available in this article, unless otherwise stated in a credit line to the data. 